\title{
Studi Komparatif Tentang Kemandirian Pada Anak Usia Taman Kanak-Kanak Ditinjau Dari Ibu Bekerja Dan Tidak Bekerja
}

\author{
Miftahul Jannah, Ifani Candra \\ Fakultas Psikologi, Universitas Putra Indonesia "YPTK" Padang, Indonesia \\ Email: antemifta@gmail.com, ifani candra@yahoo.com
}

\begin{abstract}
This study aims to determine the differences in independence of kindergarten-aged children in terms of working and nonworking mothers in the kindergartens over Talawi district, Sawahlunto sity. This research is a type of comparative research. The variable used in this study is independence. The sampling technique uses random sampling where samples from the population were carried out randomly without regard to strata that exists in the population. The sample of this study was 161 kindergarten children consisting of 49 working mothers and 112 non-working ones. The data collection method uses children's independence scale. The results of the study based on statistic calculations which were obtained a mean value of 111,69 for non-working mothers and 101,65 for working ones. Calculation of Independent Sample t-Test is obtained t-count > t-table $(3,934>1,975)$ and $P$ value $(0,00<0,05)$, then $H o$ is denied, so it can be concluded that there are significant differences in the level of independence of kindergarten-aged children referred to working and non-working mothers in the kindergartens over Talawi district, Sawahlunto city.
\end{abstract}

Keywords: Independence, kindergarten-aged children, working mothers, non-working mothers

\begin{abstract}
Abstrak
Penelitian ini bertujuan untuk mengetahui perbedaan kemandirian anak usia taman kanak-kanak ditinjau dari ibu bekerja dan tidak bekerja di TK Kecamatan Talawi Kota Sawahlunto. Penelitian ini merupakan jenis penelitian kompratif. Variabel yang digunakan dalam penelitian ini adalah kemandirian. Teknik pengambilan sampel menggunakan sample random sampling, yaitu sampel dari populasi yang dilakukan secara acak tanpa memperhatikan strata yang ada dalam populasi tersebut. Sampel penelitian ini adalah 161 anak TK, yang terdiri dari 49 ibu bekerja dan 112 ibu tidak bekerja. Metode pengumpulan data menggunakan skala kemandirian anak. Hasil penelitian berdasarkan perhitungan satatistik, didapatkan nilai mean sebesar 111,69 untuk ibu tidak bekerja dan 101,65 untuk ibu bekerja. Perhitungan Independent Sample t-Test diperoleh t-hitung > ttabel $(3.934>1,975)$ dan $\mathrm{P}$ value $(0,00<0,05)$, maka Ho ditolak, sehingga dapat disimpulkan bahwa terdapat perbedaan yang signifikan terhadap tingkat kemandirian anak usia taman kanak-kanak ditinjau dari ibu bekerja dan tidak bekerja di TK Kecamatan Talawi Kota Sawahlunto.
\end{abstract}

Kata Kunci : Kemandirian, Anak Usia Taman Kanak-Kanak, Ibu Bekerja, Ibu tidak Bekerja

\section{Pendahuluan}

Wanita adalah sosok yang selalu menarik untuk dibahas. Di era modern ini, polemik seputar wanita juga tidak pernah berhenti dibicarakan di khalayak umum. Wanita dahulu dikenal dengan istilah "kanca wingking" bagi pria, atau lebih jelasnya sebagai sosok orang nomor dua setelah suami di dalam rumah tangga (dalam Rahmawati, 2014). Kodrat utama wanita selayaknya adalah sebagai seorang isteri, sekaligus sebagai ibu rumah tangga yang bertanggung jawab dalam mengemban peran domestik atau peran natural di dalam sebuah keluarga. Peran domestik atau peran natural itu dijelaskan sebagai kodrat wanita sebagai ibu rumah tangga seperti mengandung, melahirkan, membesarkan anak, dan melayani suami (Supadiyanto dalam Rahmawati, 2014).

Menurut Moeliono (dalam Rahmawati, 2014) istilah ibu diartikan sebagai sebutan untuk seorang perempuan yang telah melahirkan kita, atau wanita yang telah bersuami. Ibu selalu dihadapkan pada stereotip masyarakat untuk bertanggung jawab penuh di dalam keluarga dan pengasuhan anak.

Dalam beberapa dekade terakhir ini, banyak perubahan yang terjadi dalam berbagai aspek kehidupan manusia (ekonomi, sosial maupun budaya), sehingga menyebabkan perubahan pada pola kehidupan keluarga, termasuk pada peran ibu. Salah satu perubahan dari peran ibu yang mencolok dan banyak menjadi perbincangan adalah peran ibu yang bekerja (Setiasih dalam Rahmawati, 2014). Yaumil (dalam Rahmawati, 2014) menjabarkan bahwa ibu bekerja adalah seorang ibu yang melakukan kegiatan secara teratur atau berkesinambungan, dalam suatu jangka waktu tertentu, dengan tujuan yang jelas yaitu menghasilkan atau mendapatkan sesuatu dalam bentuk benda, uang, jasa atau ide. 
Sedangkan dalam Undang-undang Nomor XIII tahun 2003 tentang Ketenaga kerjaan Bab X Paragraf empat Pasal 77 ayat satu menyebutkan lamanya waktu kerja pada buruh atau karyawan tujuh jam per hari untuk enam hari kerja dalam satu minggu atau delapan jam per hari untuk lima hari kerja dalam satu minggu. Namun ada juga ibu yang memilih hanya menjadi ibu rumah tangga yang tinggal dirumah untuk mengurus serta memberikan perhatian yang lebih kepada keluarga yaitu anak dan suaminya.

Ibu tidak bekerja atau sering juga disebut dengan ibu rumah tangga menurut Kamus Besar Bahasa Indonesia yang dikutip (Alwi dalam kusuma, 2017) dapat diartikan sebagai seorang istri (ibu) yang hanya mengurusi berbagai pekerjaan dalam rumah tangga (tidak bekerja dikantor). Peran ibu meliputi hal-hal seperti mengasuh dan menjaga anak, memberikan afeksi dan perlindungan, memberikan rangsangan dan pendidikan (Akbar dalam Azizah, 2019). Ibu yang tidak bekerja, tentunya memiliki waktu yang lebih banyak yang dapat dihabiskan bersama anak mereka. Mereka dapat mengatur pola makan anak, sehingga anak-anak mereka makan makanan yang sehat dan bergizi. Mereka juga dapat melatih dan mendidik anak, sehingga perkembangan bahasa dan prestasi akademik anak lebih baik jika dibandingkan dengan anak ibu yang bekerja (Engle dalam Buana, 2018).

Partisipasi ibu memiliki peran penting bagi pertumbuhan dan perkembangan anak. Seorang anak belajar pengetahuan dan keterampilan pertama dari orang tua. Secara khusus, sikap dan perilaku ibu terhadap anaknya memiliki efek positif dan negatif pada anak yang akan memiliki dampak seumur hidup. Pengaruh antara ibu dan anak memainkan peran penting yang akan membentuk pribadi anak dimasa yang akan datang (Santi dalam Buana, 2018). Terutama bagaimana sianak dapat mempersiapkan dirinya ketika akan memasuki pendidikan formal (SD, SMP dan SMA) dimana usia 56 tahun merupakan tahapan-tahapan yang disebut sebagai usia prasekolah. Pada usia 5-6 tahun ini anak biasanya mengikuti program prasekolah yaitu program taman kanak-kanak. Undang-undang Republik Indonesia nomor 20 tahun 2003 tentang sistem pendidikan nasional, pasal 28 ayat (3) menyebutkan bahwa : "Taman kanak-kanak suatu bentuk pendidikan yang diselenggarakan untuk mngembangkan kepribadian dan potensi diri sesuai dengan tahap perkembangan peserta didik". Dapat disimpulkan bahwa taman kanak-kanak merupakan pendidikan usia prasekolah yang bertujuan untuk membina tumbuh kembang anak sejak usia 5 sampai usia 6 tahun secara menyeluruh yang mencakup aspek fisik dan non fisik dengan memberikan rangsangan bagi perkembangan motorik, kognitif, emosional dan sosial.

Berdasarkan Peraturan Menteri No. 58 (dalam Rakhma, 2017) tahap perkembangan anak usia 5-6 tahun yaitu tahap perkembangan motorik, perkembangan kognitif, perkembangan sosial dan emosi. Dan selanjutnya tahap perkembangan yang harus diselesaikan pada masa ini ialah kemandirian (Harlock dalam Zuanita, 2016).

Dalam konteks anak usia 5-6 tahun, Lie dan Prasasti (dalam Kusuma, 2017) mengartikan kemandirian sebagai kemampuan anak untuk melakukan kegiatan atau tugas sehari-hari sendiri atau dengan sedikit bimbingan, sesuai dengan tahapan perkembangan dan kapasitas anak. Wiyani (2013) mengemukakan terdapat tujuh aspek kemandirian anak usia 5-6 tahun atau anak usia taman kanak (TK) yaitu : memiliki rasa percaya diri, memiliki motivasi instrinsik yang tinggi, mampu dan berani menentukan pilihan, kreatif dan inovasi, bertanggung jawab, dapat menyesuaikan diri dengan lingkungan dan tidak bergantung pada orang lain.

Anak yang mandiri cenderung berprestasi karena dalam menyelesaikan tugas-tugasnya anak tidak lagi tergantung pada orang lain. Sehingga anak bisa lebih percaya diri. Anak yang mandiri yakin, jika ada resiko, ia mampu untuk menyelesaikannya tanpa bantuan dari orang lain. Dengan begitu anak akan tumbuh menjadi orang yang mampu untuk berfikir serius dan berusaha untuk menyelesaikan sesuatu yang menjadi targetnya. Demikian juga di lingkungan keluarga dan sosial, anak yang mandiri akan mudah menyesuaikan diri. Ia akan mudah untuk diterima oleh anak-anak dan teman-teman di sekitarnya (Zimmer \& Collins dalam Irdawati, 2012). Menurut kerangka dasar kurikulum pendidikan anak usia taman kanak-kanak yang diterbitkan tahun 2007, seorang anak dapat dikatakan memiliki sikap kemandirian apabila anak mampu berinteraksi, mulai mematuhi aturan, dapat mengendalikan emosinya, menunjukkan rasa percaya diri, dan dapat menjaga diri sendiri, bila ditinjau dari hal tersebut dapat ditemukan bahwa saat ini masih banyak anak yang kemandiriannya tidak mengikuti tingkat kedewasaan usianya. Anak yang tidak dilatih mandiri sejak usia dini akan menjadi individu yang tergantung pada orang lain sampai remaja bahkan dewasa nanti. 
Tanggal 12 Mei 2019 peneliti mewawancarai 6 ibu yang memiliki anak dengan usia 5-6 tahun atau yang sedang duduk dijenjang pendidikan taman kanak-kanak, yang mana 3 orang ibu bekerja dan 3 orang lagi tidak bekerja atau hanya menjadi ibu rumah tangga saja. Hasil wawancara peneliti dengan 3 orang ibu yang bekerja mengatakan bahwa, pada usia TK ini ketika anak mereka disuruh untuk mempimpin doa belajar di depan kelas anaknya akan mengamuk, dan ketika hendak minum maupun makan anak hanya akan minum dan makan ketika ibu yang mengambilkan, begitupun ketika akan memilih baju anak selalu bertanya terlebih dahulu kepada ibunya. Para ibu yang bekerja mengatakan bahwa anak mereka bersikap seperti itu disebabkan karena intensitas waktu kebersamaan mereka dengan anaknya kurang, sehingga ketika ibu ada dirumah anak bersikap lebih manja dan meminta perhatian lebih. Sebaliknya hasil wawancara peneliti dengan 3 orang ibu yang tidak bekerja atau yang menjadi ibu rumah tangga saja mereka mengatakan bahwa pada usia TK ini anak mereka pada saat akan berangkat ke sekolah mau menyuap sendiri sarapan meraka dan mengambil minumnya sendiri, saat mandi pun anak mandi dengan sendiri, dan ketika disekolah saat disuruh gurunya untuk tampil ke depan anak mereka tidak menolak dan mau maju untuk tampil. Begitupun ketika anak meraka melakukan kesalahan anak mau untuk meminta maaf.

\subsection{Ibu Bekerja}

Ibu bekerja menurut Soedarto (dalam Rahmawati, 2014) merupakan ibu yang memiliki kegiatan secara publik dan mempunyai jadwal tertentu untuk mengembangkan hidupnya, baik secara fisik maupun psikis. Yaumil (dalam Rahmawati, 2014) juga menjabarkan bahwa ibu bekerja adalah seorang ibu yang melakukan kegiatan secara teratur atau berkesinambungan, dalam suatu jangka waktu tertentu, dengan tujuan yang jelas yaitu menghasilkan atau mendapatkan sesuatu dalam bentuk benda, uang, jasa atau ide. Sedangkan dalam Undang-undang Nomor XIII tahun 2003 tentang Ketenaga kerjaan Bab X Paragraf empat Pasal 77 ayat satu menyebutkan lamanya waktu kerja pada buruh atau karyawan tujuh jam per hari untuk enam hari kerja dalam satu minggu atau delapan jam per hari untuk lima hari kerja dalam satu minggu. Menurut Krapp dan Wilson (dalam Kusuma, 2017) ibu bekerja adalah seorang ibu yang bekerja di luar rumah untuk mendapatkan penghasilan di samping membesarkan dan mengurus anak di rumah.

\subsection{Ibu tidak Bekerja}

Ibu tidak bekerja atau sering juga disebut dengan ibu rumah tangga. Menurut Kamus Besar Bahasa Indonesia (Alwi dkk dalam Kusuma, 2017) dapat diartikan sebagai seorang istri (ibu) yang hanya mengurusi berbagai pekerjaan dalam rumah tangga (tidak bekerja di kantor). Peran ibu meliputi halhal seperti mengasuh dan menjaga anak, memberikan afeksi dan perlindungan, memberikan rangsangan dan pendidikan (Akbar \& Hawadi dalam Kusuma, 2017). Jadi, ibu rumah tangga merupakan istilah yang digunakan untuk menggambarkan seorang wanita yang telah menikah serta menjalankan pekerjaan rumah keluarga serta merawat dan memberi kasih sayang bagi anak-anaknya. Ibu yang tidak bekerja, tentunya memiliki waktu yang lebih banyak yang dapat dihabiskan bersama anak mereka. Mereka dapat mengatur pola makan anak, sehingga anak-anak mereka makan makanan yang sehat dan bergizi. Mereka juga dapat melatih dan mendidik anak, sehingga perkembangan bahasa dan prestasi akademik anak lebih baik jika dibandingkan dengan anak ibu yang bekerja (Engle dalam Buana, 2018).

\subsection{Faktor-Faktor yang Mempengaruhi Ibu Bekerja dan Tidak Bekerja}

Menurut Krapp \& Wilson (dalam Kusuma, 2017) faktor-faktor yang mempengaruhi ibu bekerja dan tidak bekerja yaitu: (a) status perkawinan dan struktur keluarga, tatistik menunjukkan bahwa wanita bekerja yang sudah menikah serta memiliki anak lebih stabil dalam menjaga stabilitas keluarganya, hal ini disebabkan oleh adanya peran pengganti ibu ketika bekerja yaitu sang ayah. Ibu yang single parent memiliki waktu lebih sulit dalam menjaga stabilitas keluarga, sehingga ini membuat mereka untuk memilih menjadi ibu rumah tangga saja. (b) jenis pekerjaan, ibu yang bekerja di bidang profesi seperti guru, perawat dan bidang yang lainnya biasanya mendapatkan kepuasaan lebih, dari wanita dengan pendidikan yang rendah dan secara tidak langsung mendapatkan kepuasan tersendiri. Mereka juga sering disebut dengan pekerja kantoran, sehingga akan sulit bila meninggalkan tuntutan pekerjaan 
walaupun meraka sedang berada di rumah. (c) tingkat pendapatan, ibu bekerja dapat lebih baik dalam membayar dan lebih banyak mendapat pilihan tentang perumahan, transportasi, dan pengaturan perawatan anak dibandingkan dengan pendapatan terbatas atau ibu yang hanya menjadi ibu rumah tangga saja. (d) tingkat pendidikan, tingkat pendidikan formal yang semakin tinggi, berakibat pada peningkatan harapan dalam hal karier dan perolehan pekerjaan dan penghasilan. Semakin tinggi tingkat pendidikan, maka akan semakin besar probabilitas perempuan yang bekerja. (e) jumlah, usia, dan kebutuhan anak, ibu dengan jumlah anak yang sedikit dan anak-anak yang sehat akan membuat ibu merasa terbantu dan lebih mudah dalam membagi waktunya antara pekerjaan dan keluarga daripada ibu dengan beberapa anak yang lahir berdekatan atau ibu yang memiliki anak penderita penyakit kronis atau mengalami kesulitan dalam perkembangan. (f) umur, Idris (dalam Kusuma, 2017) menyatakan bahwa umur akan mempengaruhi penyediaan tenaga kerja. Sebab perempuan yang berkeluarga yang masih dalam usia produktif (15-64 tahun) dapat menjadi alasan untuk memutuskan bekerja.

\subsection{Kemandirian}

Wiyani (2013) mengatakan kemandirian pada anak merupakan hal atau keadaan dapat berdiri sendiri dan merupakan karakter yang memungkinkan anak untuk tidak bergantung pada orang lain. Kemandirian adalah sikap dan perilaku dimana anak tidak mudah bergantung dengan orang lain dalam menyelesaikan tugas-tugasnya. Kemandirian juga merupakan sikap pada anak yang harus dibentuk oleh orang tua untuk membangun kepribadian mereka. Kemandirian anak usia TK adalah kemampuan anak untuk melakukan aktivitas sendiri atau mampu berdiri sendiri dalam berbagai hal dari hal-hal yang sederhana hingga mengurus dirninya sendiri dan juga anak sudah mulai belajar untuk memahami kebutuhan dirinya sendiri (Fadholi dalam Dwiasmara, 2012 ).

Menurut Santi (dalam Buana, 2018) menjelaskan kemandirian diartikan sebagai salah satu gejala taraf kematangan anak untuk dapat masuk TK. Dengan kemandirian anak terlibat pada kegiatan-kegiatan di sekolah. Kemandirian dapat diartikan sebagai suatu bentuk kepribadian yang yang terbebas dari sikap ketergantungan. Monks (dalam Putri, 2016) mengemukakan bahwa kemandirian anak meliputi perilaku mampu berinisiatif, mampu mengatasi hambatan atau masalah, mempunyai rasa percaya diri dan dapat melakukan sesuatu sendiri tanpa bantuan orang lain. Kemandirian adalah hasrat untuk melakukan segala sesuatu bagi diri sendiri.

\subsection{Aspek-aspek Kemandirian}

Menurut Wiyani (2013) kemandirian pada anak usia 5-6 tahun atau anak TK ditandai dengan beberapa aspek yaitu: (a) memiliki kepercayaan kepada diri sendiri, anak yang memiliki kepercayaan diri sendiri memiliki keyakinan untuk melakukan sesuatu sesuai yang pilihannya sendiri. (b) memiliki motivasi intrinsik yang tinggi, motivasi intrinsik merupakan dorongan yang berasal dari dalam diri untuk melakukan suatu perilaku maupun perbuatan. Motivasi yang datang dari dalam akan mampu menggerakkan anak untuk melakukan sesuatu yang diinginkannya. (c) mampu dan berani menentukan pilihan sendiri, anak yang mandiri memiliki kemampuan dan berani dalam menentukan pilihannya sendiri. (d) kreatif dan inovatif, anak melakukan atau menciptakan sesuatu atas ide yang dimiliki oleh dirinya sendiri dan suka mencoba hal-hal yang baru. (e) bertanggung jawab, anak yang mandiri akan bertanggung jawab atas keputusan yang diambilnya apapun yang terjadi. Misalnya tidak menangis ketika ia salah mengambil alat mainan, dengan senang hati mengganti dengan alat mainan yang lain yang diinginkannya. (f) mampu menyesuaikan diri dengan lingkungannya, anak yang mandiri akan cepat menyesuaikan diri dengan lingkungannya. (g) tidak bergantung pada orang lain, anak yang memiliki karakter mandiri selalu ingin mencoba sendiri dalam melakukan segala sesuatu dan dia akan tahu kapan waktunya meminta bantuan orang lain. Karakter mandiri ditunjukkan dengan adanya kemampuan untuk mengambil inisiatif dan mengatasi masalah, penuh ketekunan, memperoleh kepuasan dari usahanya, serta ingin melakukan sesuatu tanpa bantuan orang lain.

\section{Metode Penelitian}


Jenis penelitian ini adalah kuantitatif komparatif dengan variabel penelitian menurut Sugiyono (2014) adalah suatu atribut atau sifat atau nilai dari orang, obyek atau kegiatan yang mempunyai variasi tertentu yang di tetapkan oleh peneliti untuk di pelajari dan kemudian di tarik kesimpulannya. Adapun variabel yang akan diukur dalam penelitian ini adalah kemandirian.Populasi pada penelitian ini yaitu ibu bekerja dan tidak bekerja yang memiliki anak usia Taman Kanak-Kanak di Kecamatan Talawi Kota Sawahlunto yang berjumlah 250 subjek, jumlah ini diambil berdasarkan Data Peserta Didik Taman Kanak-Kanak Kota Sawahlunto tahun 2019. Teknik pengambilan sampel dalam penelitian ini adalah sample random sampling, yaitu sampel dari populasi yang dilakukan secara acak tanpa memperhatikan strata yang ada dalam populasi tersebut (Sugiyono 2014).

Alat ukur yang digunakan dalam penelitian ini adalah skala kemandirian. Menurut Azwar (2017) skala merupakan perangkat pertanyaan yang disusun untuk mengungkap atribut tertentu melalui respon terhadap pertanyaan tersebut. Skala dalam penelitian ini memiliki format respon dengan empat alternatif jawaban. Skala yang digunakan dalam penelitian ini menggunakan format respon jawaban model Likert, yaitu suatu metode pernyataan sikap yang menggunakan respon subjek sebagai penentu nilai skalanya yang telah dimodifikasi menjadi empat alternatif jawaban dan aitem-aitem dalam skala ini dikelompokkan dalam aitem favorable dan unfavorable. Bentuk skala yang digunakan untuk mengukur kemandirian menggunakan empat alternatif jawaban, yaitu SS (Sangat Setuju), S (Setuju), TS (Tidak Setuju), dan STS (Sangat Tidak Setuju). Skala penelitian akan melewati berbagai tahap analisis yaitu uji normalitas digunakan untuk mengetahui apakah populasi data terdistribusi normal atau tidak. Uji normalitas menggunakan uji kolmogorov-Smirnov. Uji homogenitas bertujuan untuk mengetahui apakah populasi bersifat homogen atau tidak. Populasi dinyatakan homogen apabila nilai signifikan besar dari 0,05 .

Selain itu dilakukan uji Validitas, sejauh mana ketepatan dan kecermatan suatu alat ukur dalam melakukan fungsi ukurnya (Azwar, 2017). Suatu item dapat dianggap memiliki daya diskriminasi yang memuaskan jika berkorelasi signifikan terhadap skor total atau jika melakukan penilaian langsung terhadap koefisien korelasi bisa digunakan batas nilai berkriteria $\mathrm{rxy} \geq 0,3$ (Priyatno, 2018). Data skala dikatakan memiliki daya beda tinggi jika koefisien korelasi lebih besar atau sama dengan 0,3 (rxy $\geq 0,3$ ) dan sebaliknya aitem skala dikatakan gugur jika koefisien korelasi lebih kecil dari 0,3 ( $r x y \geq 0,3$ ). Selanjutnya dilihat nilai reliabilitas, reliabilitas merupakan konsistensi hasil ukur, yang angkanya berkisar dari 0 sampa 1. Dimana jika nilai reliabilitas semakin mendekati 1 maka relaibilitas alat ukur semakin tinggi dan layak dipakai untuk penelitian.

\section{Hasil dan Pembahasan}

Peneliti menyebarkan 35 skala kemandirian, kemudian peneliti meminta kesediaan kepada guru disekolah anak subjek penelitian tersebut untuk mengisi skala. Sebelum pengisian skala dilakukan, terlebih dahulu peneliti menjelaskan petunjuk pengisian skala dengan singkat dan jelas kepada anak subjek, kemudian peneliti memberikan skala melalui anaknya di sekolah untuk diisi oleh ibu mereka di rumah.

\subsection{Hasil}

Koefisien Validitas skala kemandirian dengan nilai corrected item-total correlation berkisar antara 0,314 sampai dengan 0,785 , dengan reabilitas 0,951 . Uji normalitas dalam penelitian ini menggunakan uji Kolmogorov-Smirnov. Priyatno (2018) menyatakan bahwa data yang dinyatakan berdistribusi normal jika signifikansi (p) lebih besar dari 0,05. Berdasarkan hasil pengolahan data dengan menggunakan program IBM SPSS 21.0, Maka diperoleh hasil sebagai berikut:

\begin{tabular}{cccc} 
& Tabel 1. Uji Normalitas Skala Kemandirian & Status Sebaran \\
Kemandirian & KSZ & P & Normal \\
\hline Anak Ibu Bekerja & 0,784 & 0,571 & Normal
\end{tabular}

Nilai signifikan pada anak ibu bekerja $\mathrm{p}=0,571$ dengan $\mathrm{KSZ}=0,784$. Hasil tersebut menunjukkan bahwa nilai $\mathrm{p}>0,05$ artinya sebaran terdistribusi secara normal, sedangkan untuk anak ibu tidak bekerja diperoleh nilai signifikan sebesar $\mathrm{p}=0,218$ dengan $\mathrm{KSZ}=1,332$. Hasil tersebut menunjukkan 
bahwa nilai $\mathrm{p}>0,05$ artinya sebaran terdistribusi secara normal. Selanjutnya uji homogenitas dapat dilihat pada tabel 2 berikut:

\begin{tabular}{lccc} 
& \multicolumn{2}{c}{ Tabel 2. Uji Homogenitas Kemandirian } & \\
Variabel & $\mathbf{F}$ & $\mathbf{P}$ & Keterangan \\
\hline Kemandirian & 15,480 & 0,896 & Homogen
\end{tabular}

Berdasarkan tabel, maka diperoleh nilai signifikan sebesar 0,896. Karena signifikan lebih besar dari > 0,05 sehingga dapat disimpulkan bahwa kedua kelompok anak dengan ibu tidak bekerja dana anak dengan ibu bekerja berdasarkan skala kemandirian yang menjadi perbandingan bersifat homogen.

\begin{tabular}{lcccc} 
& \multicolumn{2}{c}{ Tabel 3. Hasil Uji Hipotesis Kemandirian } & & T \\
Kemandirian & Rata-rata & Std. Deviasi & T & P \\
\hline Ibu Bekerja & 101.65 & 14.532 & \multirow{2}{*}{3.934} & 0,00
\end{tabular}

Berdasarkan uji independent sample t-test di atas, maka diperoleh nilai t hitung (equal variance assume) adalah 3.934. Tabel distribusi t diperoleh pada $\alpha=5 \%: 2=2,5 \%$ (uji 2 sisi) dengan derajat kebebasan (df) $\mathrm{n}-2$ atau 161-2 $=159$. Dengan pengujian 2 sisi (signifikansi $=0.025$ ) hasil diperoleh untuk t-tabel sebesar 1.975. Jadi nilai t-hitung $>\mathrm{t}$-tabel $(3.934>1,975)$ dan $\mathrm{P}$ value $(0,00<0,05)$ maka dapat disimpulkan bahwa Ho ditolak dan Ha diterima atau terdapat perbedaan kemandirian pada anak usia taman kanak-kanak ditinjau dari ibu bekerja dan tidak bekerja. Begitu juga jika dilihat dari perolehan nilai rata-rata kemandirian terdapat perbedaan nilai rata-rata kemandirian pada anak yang ibunya bekerja dengan anak yang ibunya tidak bekerja. Nilai rata-rata yang diperoleh pada anak yang ibunya bekerja 101.65 dan pada anak yang ibunya tidak bekerja 111.69 dimana anak dengan ibu tidak bekerja memiliki tingkat kemandirian lebih tinggi daripada anak dengan ibu yang bekerja.

\subsection{Pembahasan}

Berdasarkan hasil pengolahan data yang dilakukan dengan menggunakan teknik independent sampel ttest, yang dilakukan dengan bantuan IBM SPSS Statistics 21, dimana level of significant $(\alpha) 0,05$ dan diperoleh $\mathrm{p}=0,00$ serta diperoleh t-hitung > t-tabel $(3.934>1,975)$, maka Hipotesis diterima (Ho ditolak) artinya ada perbedaan kemandirian pada anak usia taman kanak-kanak ditinjau dari ibu bekerja dan tidak bekerja, sedangkan nilai rata-rata kemandirian yang diperoleh dari independent sample t-test antara anak yang ibunya bekerja adalah sebesar 101.65 dan anak yang ibunya tidak bekerja memiliki rata-rata sebesar 111.69. Dari penjelasan di atas dapat menggambarkan bahwa antara anak yang ibunya bekerja dengan anak yang ibunya tidak bekerja terdapat perbedaan kemandirian yang signifikan karena mempunyai perbedaan yaitu 10.4. Maka hasil pengolahan data dari sampel yang terdiri dari 161 orang dengan ibu yang bekerja sebanyak 49 orang dan ibu yang tidak bekerja sebanyak 112 orang menunjukkan bahwa ada perbedaan kemandirian pada anak usia taman kanakkanak ditinjau dari ibu bekerja dan tidak bekerja. Hal ini sesuai dengan pendapat Aggarwal (dalam Buana, 2018) bahwa anak dari ibu yang bekerja kurang mandiri dalam kesehariannya dibandingkan dengan ibu yang tidak bekerja dan anak dari ibu yang tidak bekerja ternyata lebih kreatiif, antusias, asertif, percaya diri dan tidak depresi. Begitu juga dengan pendapat Salsabila (dalam Buana, 2018) bahwa tingkat kemandirian anak usia dini yang diasuh oleh ibu yang bekerja seharian penuh di luar rumah dengan ibu yang seharian penuh di rumah akan berbeda. Seorang anak yang diasuh oleh ibu yang bekerja di luar rumah seharian penuh akan mengalami kesusahan mengatur komunikasi terhadap ibu, sehingga anak kesulitan dalam memperoleh informasi dan pengarahan mengenai kemandirian pada anak. Di dukung dengan pendapat Wiyani (2013) bahwa status pekerjaan ibu mempengaruhi tingkat kemandirian anak. Wiyani (2013) juga mengemukakan pembentukan karakter kemandirian anak tidak terlepas dari peran orangtua dan pengasuhan yang diberikan orangtua terhadap anaknya. Apabila seorang anak sejak kecil dilatih untuk mandiri, ia tidak akan merasa takut ketika harus keluar dari asuhan orangtua untuk hidup mandiri. Pola asuh ayah dan ibu mempunyai peran nyata dalam membentuk karakter mandiri anak usia dini. Toleransi yang berlebihan, pengasuhan yang berlebihan dari orangtua yang terlalu keras kepada anak dapat menghambat pencapaian kemandiriannya. Maslow (dalam Kusuma, 2017) mengemukakan bahwa kemandirian berkembang melalui proses keragaman 
manusia dalam kesamaan dan kebersamaan. Kemandirian pada seorang anak merupakan suatu kekuatan internal individu yang diperoleh melalui proses realisasi kemandirian dan proses menuju kesempurnaan. Anak akan mandiri jika dimulai dari keluarganya karena proses kemandirian seorang anak sangat dipengaruhi oleh lingkungannya. Perlu adanya pendampingan dan arahan dari orangtua secara bijak sesuai dengan kebutuhan anak, tidak berlebihan maupun tidak kekurangan untuk memaksimalkan pencapaian kemandirian pada anak. Pemberian arahan dan bantuan kepada anak secara berlebihan akan menghambat proses kemandirian anak, begitu pula apabila pemberian bantuan dan arahan diberikan secara minimal. Hubungan keluarga yang hangat akan membentuk kondisi lingkungan yang menyenangkan dan mendorong perkembangan anak, sehingga anak tidak akan merasa canggung maupun minder (Wiyani, 2013).

\section{Kesimpulan dan Saran}

Berdasarkan hasil dari penelitian dan pembahasan yang dilakukan sebelumnya, maka dapat ditarik kesimpulan yang sekaligus merupakan dari tujuan penelitian, yaitu adanya perbedaan kemandirian pada anak usia taman kanak-kanak ditinjau dari ibu bekerja dan tidak bekerja. Kesimpulan ini dapat diperkuat dengan melihat hasil perbedaan nilai rata-rata yang menunjukkan adanya perbedaan kemandirian yang signifikan antara anak yang diasuh oleh ibu bekerja dan ibu tidak bekerja. Dan dari hasil penelitian ini, maka peneliti mencoba memberikan beberapa saran yang dapat dijadikan sebagai pertimbangan yang diharapkan dapat bermanfaat, diantaranya : Bagi ibu bekerja yang memiliki anak usia taman kanak-kanak agar dapat mencari pengetahuan dan referensi terhadap bagaimana pekembangan kemandirian anak sesuai usianya. Memanfaatkan waktu luang sebaik mungkin dengan anak, dengan cara menjadi role model bagi anak, seperti mengajak anak untuk membersihkan mainannya kembali setelah bermain, melalui cara ini sesuai dengan perkembangannya anak akan mulai terbiasa membersihkan mainnannya sendiri tanpa diminta. Begitupun dengan kegiatan-kegiatan sebelum tidur seperti mencuci tangan, menggosok gigi atau hal-hal lain yang bisa ibu terapkan untuk meningkatkan kemandirian sianak ketika ibu sudah berada dirumah. Dari sini karakter anak mulai terbentuk, yaitu menajdi pribadi yang mandiri. Bagi ibu tidak bekerja yang memiliki anak usia taman kanak-kanak agar dapat mencari pengetahuan dan referensi terhadap bagaimana perkembangan kemandirian anak sesuai usianya. Berbagai hal dapat dilakukan bagi ibu yang memiliki waktu penuh dengan sibuah hati, salah satunya dengan memberikan kesempatan (ketika sianak ingin menuangkan air ke gelas, biarkan ia menuangkan sendiri. Ketika ia gagal, maka terima kegagalannya, karena dengan menerima kegagalan sianak, mendukungnya untuk mencoba lagi. Selain itu anak belajar untuk tidak menyalahkan siapapun). Selanjutnya bagi sekolah agar dapat memperbanyak dan mencari referensi-referensi tentang bagaimana cara menyeimbangkan kemandirian anak usia taman kanakkanak pada ibu yang bekerja dan tidak bekerja, sehingga antara anak usia taman kanak-kanak yang memiliki ibu bekerja tidak tertinggal jauh tingkat kemandiriannya dari anak usia taman kanak-kanak yang memiliki ibu tidak bekerja atau full time dirumah. Bagi siswa dan guru taman kanak-kanak, pertama bagi siswa agar dapat mengikuti kegiatan-kegiatan yang diadakan guru disekolah dalam rangka meningkatkan kemandirian. Salah satu kegiatan yang bisa dilakukan ialah dengan mengajak anak didik dan anak didik mengikuti kegiatan tersebut dengan baik, yaitu menyusun balok secara berkelompok, kegiatan ini dapat melatih kepercayaan diri anak untuk dapat bekerja sama dalam kelompok ataupun dengan orang lain. Setelah kegaitan menyusun balok selesai, maka anak didorong untuk membereskan dan merapikan kembali balok yang digunakan secara berkelompok. Sehingga melalui kegaiatan ini kemandirian anak akan berkembanag sesuai usia perkembangannya. Sedangkan bagi gurunya agar dapat untuk menambah pengetahuan tentang cara mendidik dan ciri-ciri anak didik yang sudah mandiri saat mengikuti taman bermain. Yang terakhir yaitu bagi peneliti selanjutnya yang memiliki keinginan untuk melakukan penelitian lebih lanjut untuk mengetahui perbedaan kemandirian pada anak usia taman kanak-kanak ditinjau dari ibu bekerja dan tidak bekerjaa, maka untuk penelitian selanjutnya dapat mengambil sampel dari geografis tempat yang berbeda atau dari tingkat perkembangan kognitif ataupun motorik anak. Peneliti selanjutnya dapat mempertimbangkan untuk melakukan penelitian lain tentang perbedaan kemandirian anak usia taman kanak-kanak ditinjau dari kehidupan sosial orangtua. 


\section{Daftar Rujukan}

Azizah, Meilinda. 2019. Hubungan Pola Asuh Ibu Bekerja dan Tidak Bekerja terhadap Kemandirian Anak Usia 5-6 Tahun di TK Se-Kelurahan Cinere Depok. Skripsi: Fakultas Ilmu Tarbiyah dan Keguruan UIN Syarif Hidayatullah Jakarta.

Azwar, Saifuddin. 2017.Metode Penelitian Psikologi. Yogyakarta: PustakaPelajar.

Buana, Nila Putri. 2018. Kemandirian Anak Usia Prasekolah Ditinjau Dari Ibu Bekerja dan Tidak Bekerja. Skripsi: Fakultas Psikologi Universitas Muhammdiyah Malang.

Dwiasmara, Yulistyas. 2012. Studi Komparasi Kemandirian Anak Taman Kanak-Kanak (TK) Di Program Fullday dan Reguler. Skripsi: Fakultas Keguruan dan Ilmu Pendidikan Universitas Muhammadiyah Surakarta.

Irdawati, Danang Danu Suseno. 2012. Hubungan Antara Pola Asuh Orangtua dengan Kemandirian Anak Usia Prasekolah Di TK Aisyiyah Mendungan Sukoharjo. Jurnal Keperawatan: Sukaharjo.

Kusuma, Lia. 2017. Perbedaan Kemandirian Anak Usia 5-6 Tahun ditinjau Dari StatusBekerja Ibu Di TK SeKelurahan Tamanagung Muntilan. Skripsi: Fakultas Ilmu Pendidikan Universitas Negeri Yogyakarta.

Priyatno, 2018. Mandiri Belajar Analisa Data dengan SPSS. Yogyakarta: Mediakom.

Rahmawati, Gita M. 2014. Harga Diri Ibu Rumah Tangga Tidak Bekerja. Skripsi: Fakultas Psikologi Universita Katolik Siegijapranata Semarang.

Rakhma, Eugenia. 2017. Menumbuhkan Kemandirian Anak. Jogjakarta: Stiletto Book.

Sugiyono, 2014. Metode Penelitian Kuantitatif, Kualitatif dan $R$ \& D. Bandung: Alfabeta

Wiyani, Novan Ardy. 2013. Bina Karakter Anak Usia Dini. Jogjakarta: Ar-ruzz Media.

Zuanita, Finda Nurma. 2016. Hubungan Pola Asuh Orang Tua dengan Tingkat Kemandirian Pemenuhan ADS (Aktivitas Dasar Sehari-hari) Anak Usia Prasekolah Di TK BOPKRI Gondolayu Yogyakarta. Skripsi: Program Studi Ilmu Keperawatan Sekolah Tinggi Ilmu Kesehatan Jenderal Achmad Yani Yogyakarta.

Dewinda, H. R. (2019). HUBUNGAN ANTARA KOMUNIKASI INTERPERSONAL DENGAN ORGANIZATIONAL CITIZENSHIP BEHAVIOR PADA KARYAWAN DEPARTEMEN SUMBER DAYA MANUSIA PT. SEMEN PADANG. Psyche 165 Journal, 12(2), 202-209. 